\title{
DESIGN AND FEATURES ANALYSIS OF GENERALIZED ELECTRONIC CONTENT-COMMERCE SYSTEMS ARCHITECTURE
}

\author{
Victoria Vysotska ${ }^{1}$, Lyubomyr Chyrun ${ }^{2}$, Pavlo Kozlov ${ }^{1}$ \\ ${ }^{1}$ Lviv Polytechnic National University, Information Systems and Networks Department, ${ }^{2}$ Lviv Polytechnic National University, Software Department
}

Abstract. This article is dedicated to the development of standardized methods and software for information resources processing in electronic content commerce systems (ECCS). In this paper an actual scientific problem of methods and tools development and research of information resources processing in ECCS was solved with the use of designed classification, mathematical tools, software and generalized ECCS architecture.

Keywords: Information management, electronic commerce

\section{PROJEKTOWANIE ORAZ ANALIZA FUNKCJI UOGÓLNIONEJ ARCHITEKTURY SYSTEMÓW HANDLU TREŚCIĄ ELEKTRONICZNĄ}

Streszczenie. Artykut jest poświęcony rozwojowi znormalizowanych metod i oprogramowania do przetwarzania zasobów informacyjnych w systemach handlu treścia elektroniczna (ECCS). W artykule pokazano rozwiązania aktualnego problemu naukowego projektowania i badań przetwarzania zasobów informacyjnych w ECCS z wykorzystaniem metod i dedykowanych narzędzi matematycznych, oprogramowania i uogólnionej architektury ECCS.

Słowa kluczowe: zarządzanie informacją, handel elektroniczny

\section{Introduction}

This article describes the commerce content lifecycle phases and management features and services. The detailed analysis of content management systems and prospects of electronic content commerce systems implementation are made. A detailed classification of electronic commerce systems and electronic content commerce systems are developed. Business processes, content flows, tools, content management systems models are analyzed. Content management methods/tools and their advantages/disadvantages are described.

Modern Internet progress causes increasing needs in productive/strategic information and new forms realization for information service [1-38]. An information product or commercial content is documented information that is prepared in accordance due to users needs [2]. Information service is a lot of actions for commercial content users providing. The Internet market is a totality of economic, law, organizational and program relations for information products and services sale/purchase between developers/providers and users $[2,6,7,8,9]$.

\section{The recent researches and publications analysis}

The content term has few interpretations according to the application direction $[1,2]$. For the computer science area it's informatively meaningful filling (for example: graphics, multimedia) of the information resource [2]; set of all values, operated by information system [2]; generalized notion of data without pre-defined structure [2, 9]. Information resource is a set of structured/non structured content arrays in information system, for example: libraries, archives/repositories, funds, portals, directories/vocabularies, data banks/bases/warehouses, electronic commerce systems etc. [1,2]. Commerce content is determined as information resources filling in electronic content commerce system (ECCS); ECCS business process object (for example: article, software, book etc.); structured set of logically completed information, which is an object of relations between user and ECCS; data set without pre-defined structure, that exist only in electronic form; commercial appointment information, indivisible in time; main factor of ECCS activity area formation, functioning and appointment [1, 2, 33-38].

Content distribution market provides technological progress of operational content preparing. It is available through information resources and depends on perception, image, and preservation of his values. Moderators provide content formalization, analysis, structuring and formatting for problems tracking and their resolving in the information system. Content structuring process is unit determination, methods and rules of their combination amongst themselves from smaller to bigger content elements formation [2]. Formed content arrives to data base/warehouse, where it's thematic/ features are defined, for example: electronic publications with bigger demand coefficient from information resource visitors/users (Fig. 1). Structured content is concentrated in ERP/CRM and not only. Non structured content is concentrated in e-mail's, freeform working papers and collective work provision tools and is stored in ECMS and not only [2].

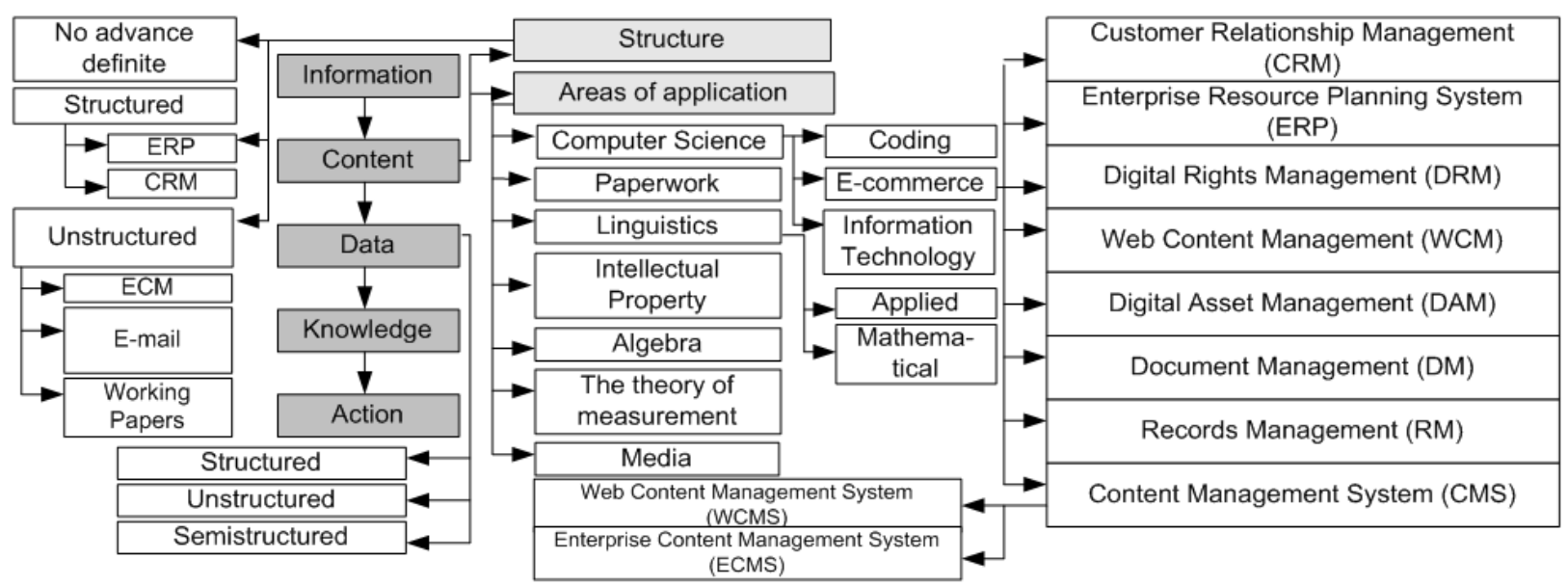

Fig. 1. Structure and directions of content using classification 
Content lifecycle is complicated process. Content passes through different stages/phases of publication. It has properties, as teamwork, collaboration, digital assets and versions, inventory management that are supported by various technologies [2]. Existing e-commerce tools are giving system administrator/ moderator various content management possibilities (formatting, formalizing, structuring, adding, editing, deleting), but does not solve automating information resource processing problem. So for content lifecycle realization tools that are producing content formation, management and support processes are required. Content is characterized by renewability/modification time and has a set of specific properties (Fig. 2). Content volume is measured in information quantity units (bit/byte). Content quantity/quality characterizes user's interest degree to information resource, where it is located [2]. Web content is textual, visual, sound content or part of information resource user's experience. Business process management is an important phase of commercial content lifecycle. Commercial content parameter determining as topicality/accuracy (latest information about defined question) requires clear business process management on the basis of workflow.
Economic content is an element of e-business object of economic activity (Fig. 3). Content market based on Internet with information technologies of knowledge management is a tool. It helps e-business functioning with commercial content spreading and its profitability growth for e-commerce subjects $[1,2,9$, 17-20]. Commercial content is object of purchase sale between e-commerce members [2], for example:

- information block that is divided into blocks (exchange rates, weather block),

- other sections/resources, announcements materials (with links),

- referential information (holiday dates, event announcements, and train timetable),

- entertaining information (anecdote of the day),

- advertisement,

- buttons and information partners links,

- statistic buttons.

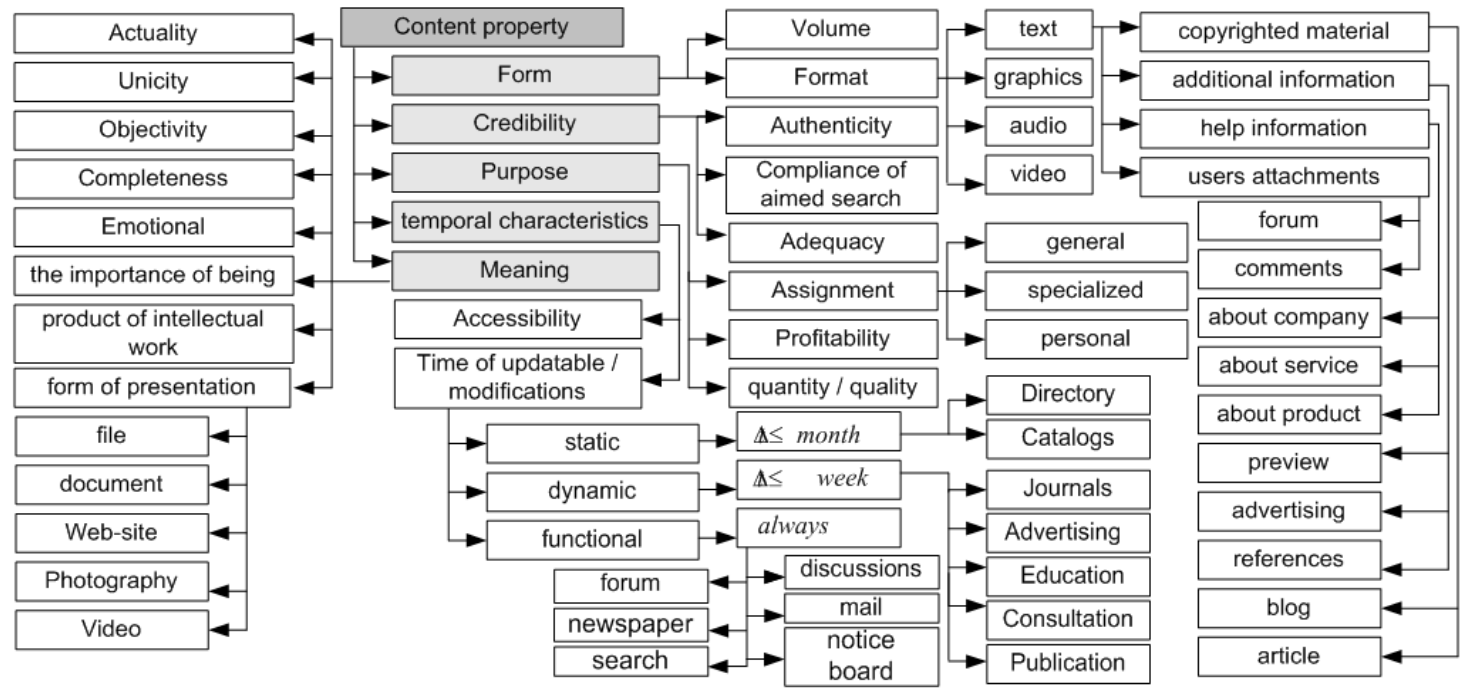

Fig. 2. Main content properties

\begin{tabular}{|c|c|}
\hline Subscription Form \\
of newsletter \\
\hline forms of services \\
\hline forum \\
\hline notice board \\
\hline chat \\
\hline voting \\
\hline adding news \\
\hline comments \\
\hline Guest Books \\
\hline contests \\
\hline tests \\
\hline games \\
\hline borlionk \\
\hline advertising \\
\hline article \\
\hline raster \\
\hline \\
\hline
\end{tabular}

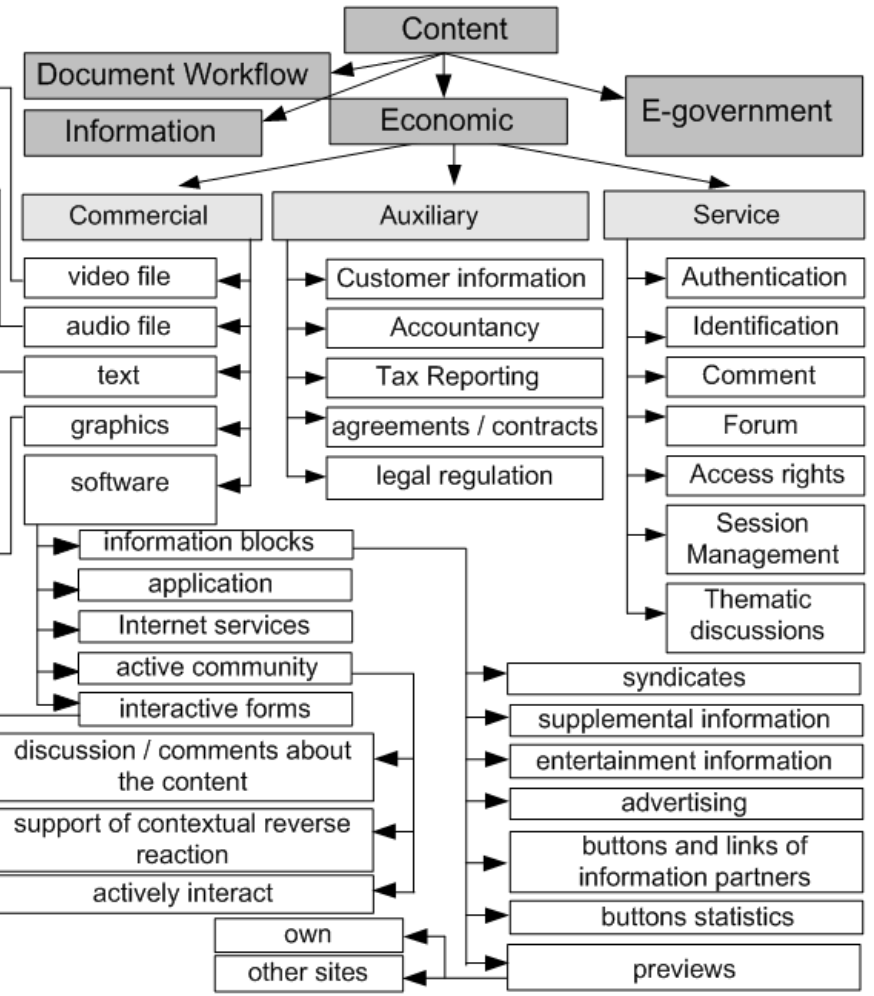


Table 1. CMIS standard characteristics [17-20]

\begin{tabular}{|c|c|c|}
\hline Name & Characteristic & Explanation \\
\hline \multirow{8}{*}{ 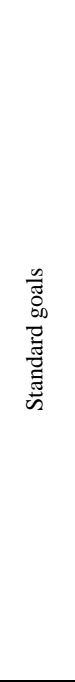 } & Single service & $\begin{array}{l}\text { It allows application to determine operations set } \\
\text { that are performed in the current context, on behalf } \\
\text { of a specific user on a specific object. }\end{array}$ \\
\hline & Data integration & $\begin{array}{l}\text { This work is to provide new applications with } \\
\text { existing repositories of archival data and accumu- } \\
\text { lated content in their. }\end{array}$ \\
\hline & Authenti-cation & $\begin{array}{l}\text { It remains for repositories, protocols and appli- } \\
\text { cation }\end{array}$ \\
\hline & $\begin{array}{l}\text { Language } \\
\text { independence }\end{array}$ & $\begin{array}{l}\text { Independent content management of different } \\
\text { repositories through Web-services. }\end{array}$ \\
\hline & Web 2.0 support & $\begin{array}{l}\text { Web-services and Web } 2.0 \text { interfaces providing } \\
\text { (IT that simplifies application development } \\
\text { for Internet perception user changing). }\end{array}$ \\
\hline & Openness & $\begin{array}{l}\text { Creation and support of independent platform from } \\
\text { content language. }\end{array}$ \\
\hline & $\begin{array}{l}\text { Content } \\
\text { formation }\end{array}$ & $\begin{array}{l}\text { Composite applications and content collages } \\
\text { development support from several sources, that } \\
\text { looks like single unit }\end{array}$ \\
\hline & $\begin{array}{l}\text { Actions } \\
\text { permissions }\end{array}$ & $\begin{array}{l}\text { Repository determinates the allowed actions based } \\
\text { on the internal model of authorization. }\end{array}$ \\
\hline \multirow{8}{*}{ 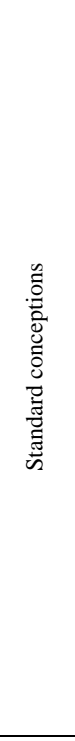 } & $\begin{array}{l}\text { Repository } \\
\text { abstraction }\end{array}$ & $\begin{array}{l}\text { It is independent from the main mechanisms for } \\
\text { data storage. The standard defines interfaces } \\
\text { for the abstraction storage formation. }\end{array}$ \\
\hline & Object typing & $\begin{array}{l}\text { Basic types of objects in the repository are } \\
\text { documents, folders, relationships and politics. }\end{array}$ \\
\hline & $\begin{array}{l}\text { Types } \\
\text { detalisation }\end{array}$ & $\begin{array}{l}\text { Repository determines additional object types for } \\
\text { any of the base types. }\end{array}$ \\
\hline & $\begin{array}{l}\text { Object } \\
\text { properties }\end{array}$ & $\begin{array}{l}\text { An object type determines properties schemes that } \\
\text { are allowed/required for object. }\end{array}$ \\
\hline & $\begin{array}{l}\text { Independence } \\
\text { from Protocol }\end{array}$ & $\begin{array}{l}\text { The data model and services are independent } \\
\text { of the protocol (are supported protocols based on } \\
\text { SOAP / REST), that are used for service running. }\end{array}$ \\
\hline & Services & Content management services availability. \\
\hline & $\begin{array}{l}\text { Documents } \\
\text { versions support }\end{array}$ & $\begin{array}{l}\text { Document objects can be versions (objects } \\
\text { of folder, relations and politics are not versions). } \\
\text { All methods for documents sending/receiving } \\
\text { indicate whether they belong to a particular } \\
\text { version of the document or always have the latest } \\
\text { version. }\end{array}$ \\
\hline & Multiregistration & $\begin{array}{l}\text { Repository has the ability to support several } \\
\text { document feeding in zero/one/few folders simulta- } \\
\text { neously. It does not give folders few times. }\end{array}$ \\
\hline \multirow{4}{*}{$\begin{array}{l}\sum_{0}^{0} \\
\substack{0 \\
0} \\
0 \\
0\end{array}$} & Documents & $\begin{array}{l}\text { Individual objects in repository that include } \\
\text { /exclude one content flow. }\end{array}$ \\
\hline & Folders & $\begin{array}{l}\text { Organizational containers in which store } \\
\text { documents/folders. }\end{array}$ \\
\hline & Relations & $\begin{array}{l}\text { Free connections only between two objects } \\
\text { (documents, objects) in repository. }\end{array}$ \\
\hline & Politics & $\begin{array}{l}\text { An administrative rules sets, which are applied } \\
\text { to objects. }\end{array}$ \\
\hline \multirow{6}{*}{ 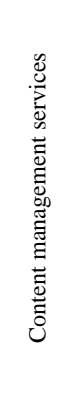 } & $\begin{array}{l}\text { Type } \\
\text { identification }\end{array}$ & $\begin{array}{l}\text { Identification of object type and other data } \\
\text { in repository, including information about addi- } \\
\text { tional possibilities offered specific repository. }\end{array}$ \\
\hline & Modification & Objects creation, editing and deleting. \\
\hline & Distribution & Documents distribution in multiple folders. \\
\hline & Navigation & $\begin{array}{l}\text { Implementation of navigation in repository and } \\
\text { search by folders hierarchy. }\end{array}$ \\
\hline & Versification & $\begin{array}{l}\text { Object (documents) versions creation and access } \\
\text { providing to version history. }\end{array}$ \\
\hline & Search criteria & $\begin{array}{l}\text { Samples in any objects repository that satisfy the } \\
\text { user-defined criteria for search order. }\end{array}$ \\
\hline
\end{tabular}

Economic content is an element of e-business object of economic activity (Fig. 3). Content market based on Internet with information technologies of knowledge management is a tool. It helps e-business functioning with commercial content spreading and its profitability growth for e-commerce subjects $[1,2,9$, 17-20]. Commercial content is object of purchase sale between e-commerce members [2], for example:

- information block that is divided into blocks (exchange rates, weather block),

- other sections/resources, announcements materials (with links),

- referential information (holiday dates, event announcements, and train timetable),

- entertaining information (anecdote of the day),

- advertisement,

- buttons and information partners links,

- statistic buttons.

EMC, IBM, Microsoft Alfresco, Open Text, Oracle and SAP corporations developed Content Management Interoperability Services (CMIS) specifications on Web-services interface for content management systems interaction (Table 1).

CMIS does not specify security system and its parameters configuration and does not solve integration problems [2, 9, 17-20]. Interoperable Content Application tools interact with content from different repositories via service interface and special module CMIS Implementation that is developing by each CMIS member $[2,17-20]$.

\section{Objectives}

Electronic commerce is an e-business separate case (Table 2), where commerce content is valuable asset $[1,2,9]$. For fast business growth effective e-commerce policy is taken into account: intellectual property protection; interactive confidence (content protection/privacy); free/open trading; active investments in its infrastructure [1,2].

Table 2. Main determinations of e-commerce notion

\begin{tabular}{|c|l|}
\hline No & \multicolumn{1}{|c|}{ Definition } \\
\hline 1 & $\begin{array}{l}\text { All forms of goods trade and services by using electronic tools, including } \\
\text { Internet. It allows to develop new markets, but raises the question } \\
\text { of information security and intellectual property [1, 2] that solves the } \\
\text { digital legal management. }\end{array}$ \\
\hline 2 & $\begin{array}{l}\text { A large set of interactive methods for providing services or selling goods } \\
\text { to consumers. }\end{array}$ \\
\hline 3 & $\begin{array}{l}\text { Any form of business operations where the parties interact through IT, } \\
\text { and not in physical contact or exchange. For example: electronic data } \\
\text { interchange (EDI) systems are a processes set of content creating, } \\
\text { processing, control, transmission, reception, storage, use and disposal that } \\
\text { are performed by the integrity verifying and fact confirmation of its receipt } \\
\text { if necessary [1,2]. }\end{array}$ \\
\hline 4 & $\begin{array}{l}\text { The use of electronic communications and electronic data processing } \\
\text { technologies for the relationship establishment and modification, for value } \\
\text { creation between institutions and organizations and individuals. }\end{array}$ \\
\hline 5 & $\begin{array}{l}\text { Doing business in online mode in the following areas: direct sales of goods } \\
\text { and services; banking and billing; safe placement of content; corporate } \\
\text { procurement. }\end{array}$ \\
\hline
\end{tabular}

E-commerce system (ECS) is information system with functions set for automatic support of processes in electronic commerce (Fig. 4) [1, 2, 9].

Electronic commerce systems are classified by type of e-commerce member's relationship and main kind of business process flow (Table 3, Fig. 5) [2]. ECS can be classified by type of activity: global electronic marketing; Media interactivity, that changes the paradigm of advertising business and market research; active progress of e-commerce direction; operative services provided at a distance (counseling, law/accounting support, etc.); distance work (distributed offices organization for collaboration from different world parts). 
Communication overhead is insignificant. The result is the global markets opening for small and medium businesses, competitiveness and proposals set improving; development of new approaches of ECS modeling and designing; new product implementation as commercial content [1,2]. ECS implementation is difficult through such problems as costs, value, safety, interoperability $[1,2,9]$.
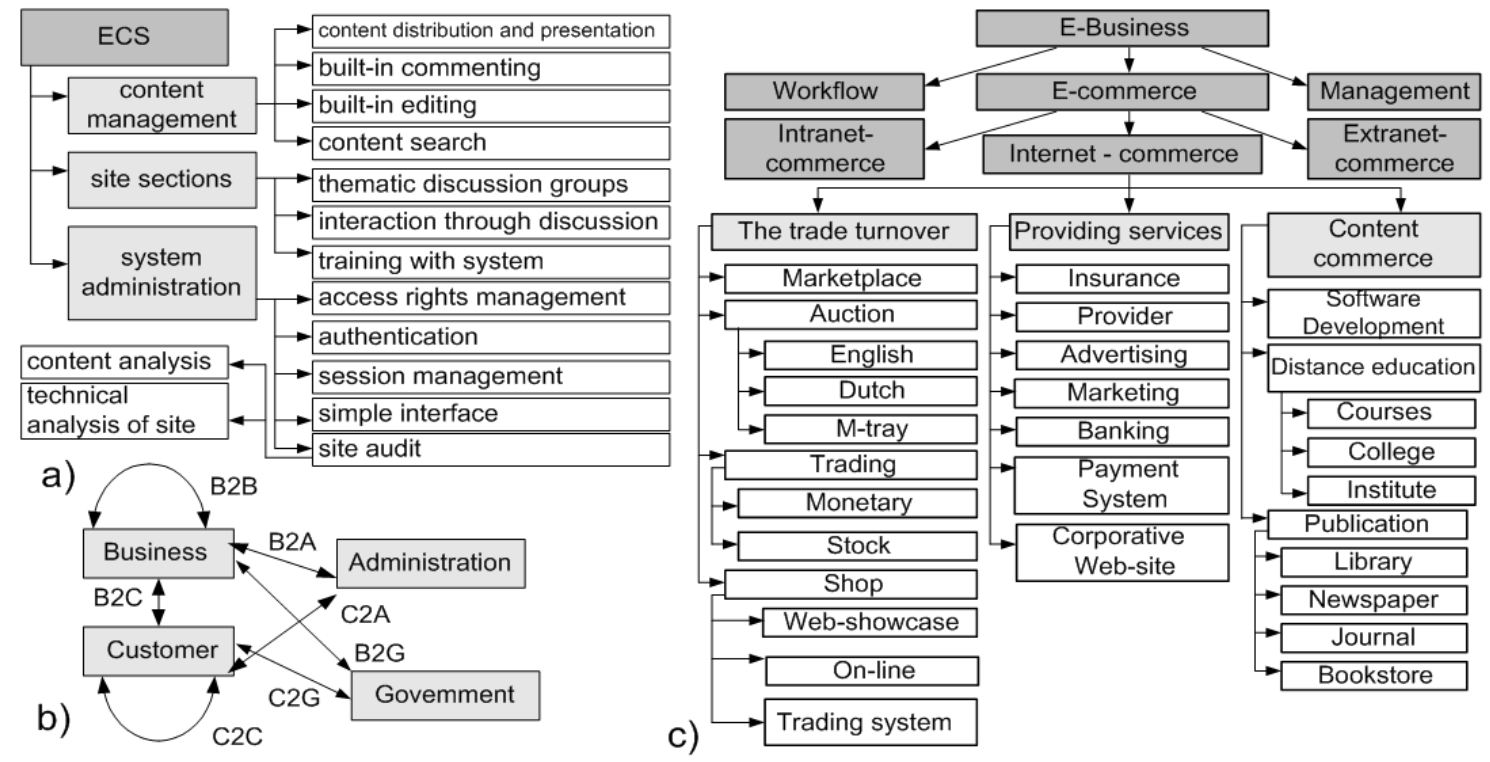

The Internet provides an additional alternative way of e-business conducting. But the ECS should be integrated with existing systems for avoiding of functional possibilities duplication and their applicability, current work and reliability support. ECS is able to automatically content exchanging. Because business reaches cost reductions, improved operation and dynamics increasing of surplus value chains creation.

Fig. 4. E-commerce systems a) functions, b) relationships and c) typology

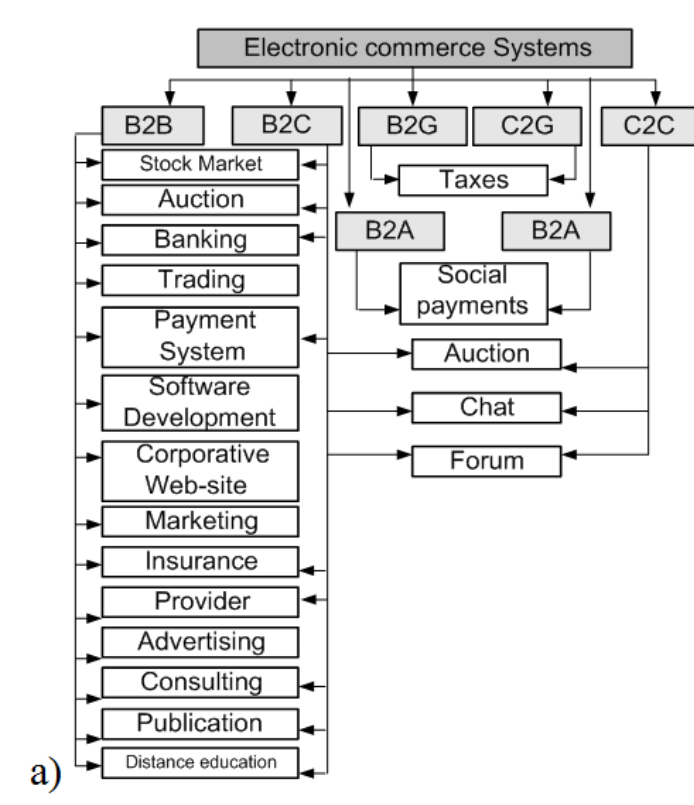

Fig. 5. Electronic content business a) categories and b) processes

\section{The main results of the research}

Electronic content commerce system (ECCS) is information system of automated support of information e-commerce resources processing and commercial content promoting on global markets (Fig. 6a).

SEC development prospects are caused by economical social and electronic technological, organizational and legal factors. Among them there are significant factors as Internet multifunction, the economic activity liberalization and the economy globalization, the organizational/technical availability and the financial/economic efficiency of e-commerce for market players.

ECCS are divided into universal, specialized, independent and/or highly specialized systems; components of the traditional publisher; corporative, proprietary and/or rented systems

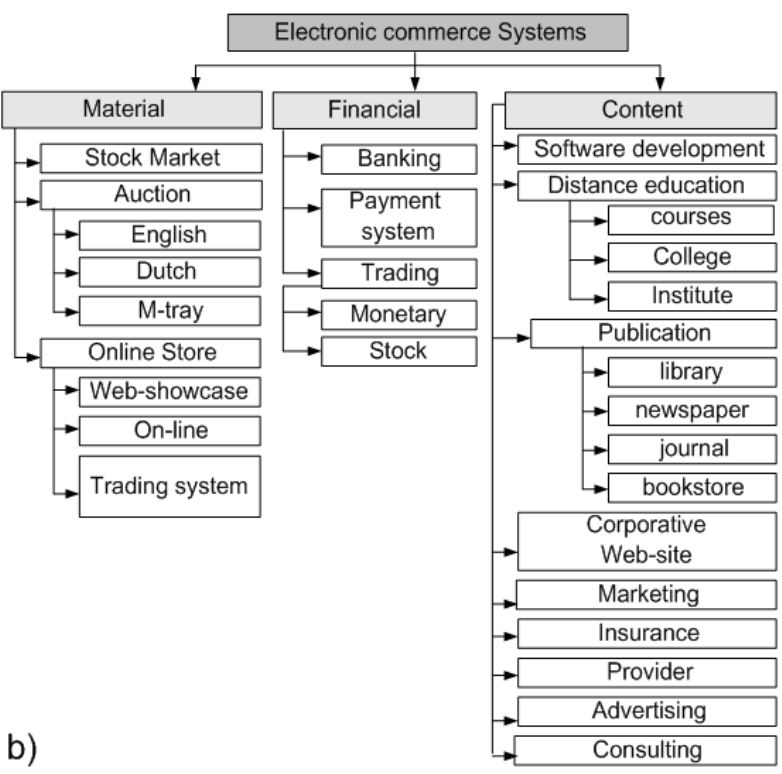

This range depends on the content of information technology type, status, creation method. Content is an important factor of e-business riving (Fig. 6b) with following features as a significant increase in demand for content; fundamentally new technology introduction based on rapid development of e-commerce; rapid expansion of software for ECCS creating. The main areas of marketing services are products/services markets research and business partners search (Fig. 7a).

Content consumers satisfy the information needs of the following ways as information resources or data bases/warehouses visiting; content receiving periodically by e-mail; connecting to specialized information systems/networks. Among the main problems of consulting content providing (Fig. 7b) are isolated non-payments of debtors, cost increasing, tax payments minimization, salling products on the market. 
The main perspective research directions are improving /researching methods of e-business strategic planning and improvement; management systems implementation of quality, personnel and content flows; e-commerce technologies implementation. The content flows number is significantly greater than of products displacement ways in industrial plants (Fig. 8).
A considerable part of the content flows consists of easily formalized and automated procedures (Fig. 9) [1]. ECCS is a core of content exchange process. Information resource processing in ECCS is a powerful and effective tool of e-business.

The main e-commerce tool is the electronic content commerce system. Its Web-site is the link between users and system (Table 4). a)

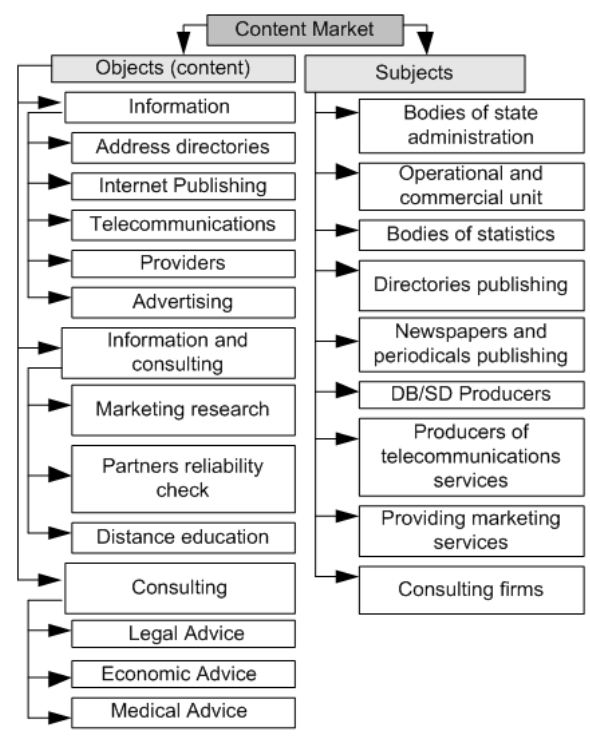

b)

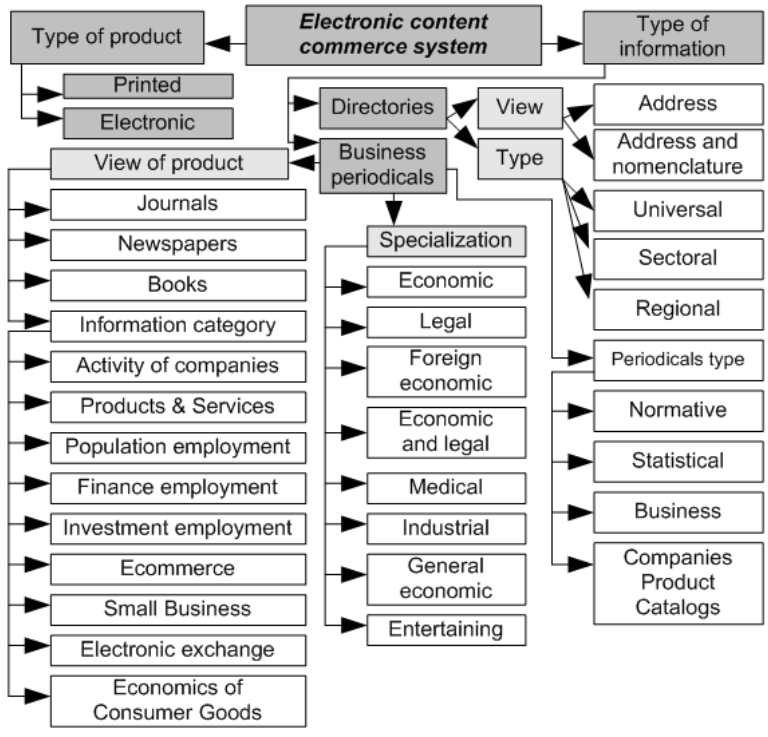

Fig. 6. E-commerce content classification by type of: a) commercial activity and b) commercial content

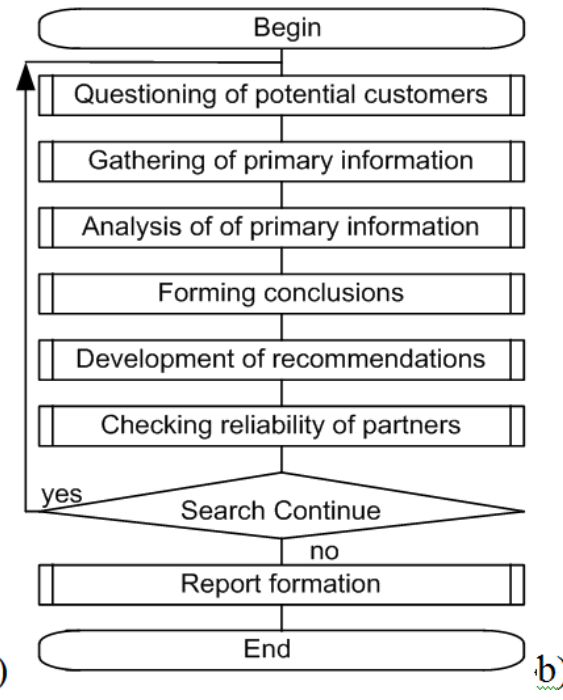

Fig. 7. Stages of granting a) marketing and b) consulting services

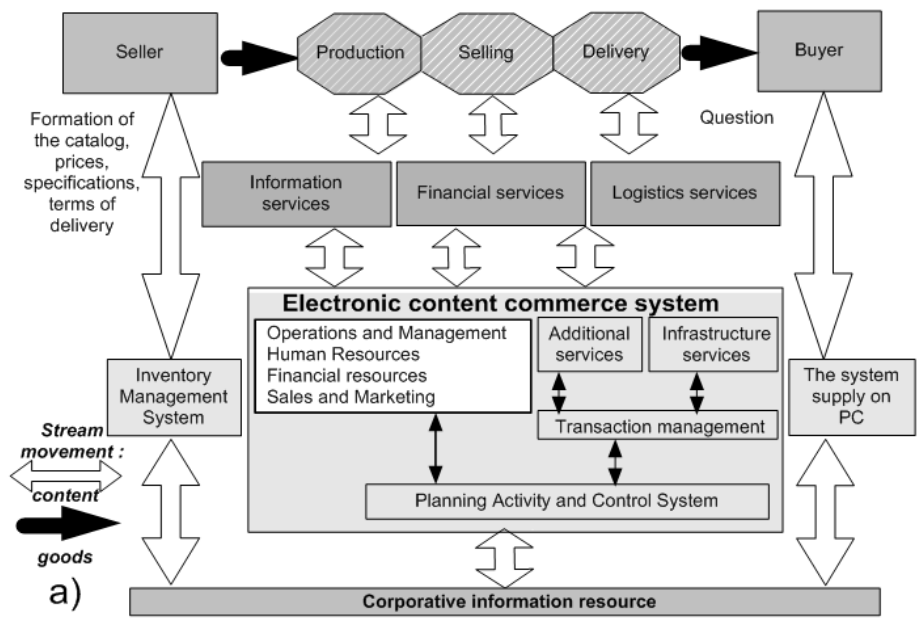

b)

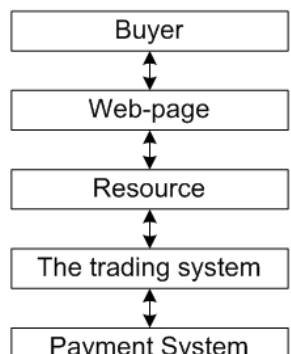

c)

Payment System

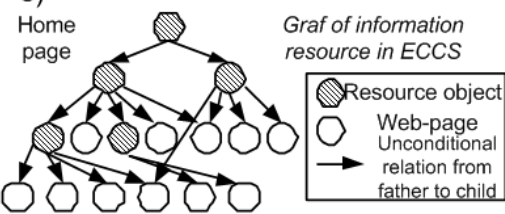

Fig. 8. Content flow scheme in e-commerce systems 

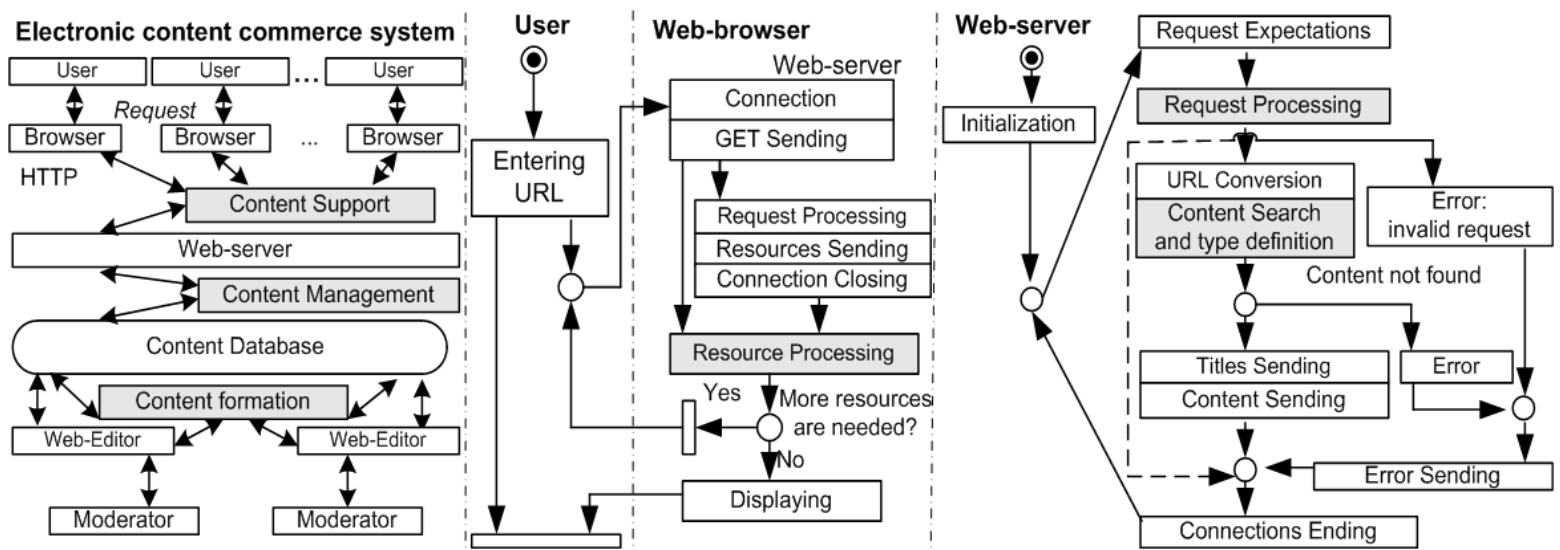

Fig. 9. Electronic commerce system functioning scheme, developed by [1]
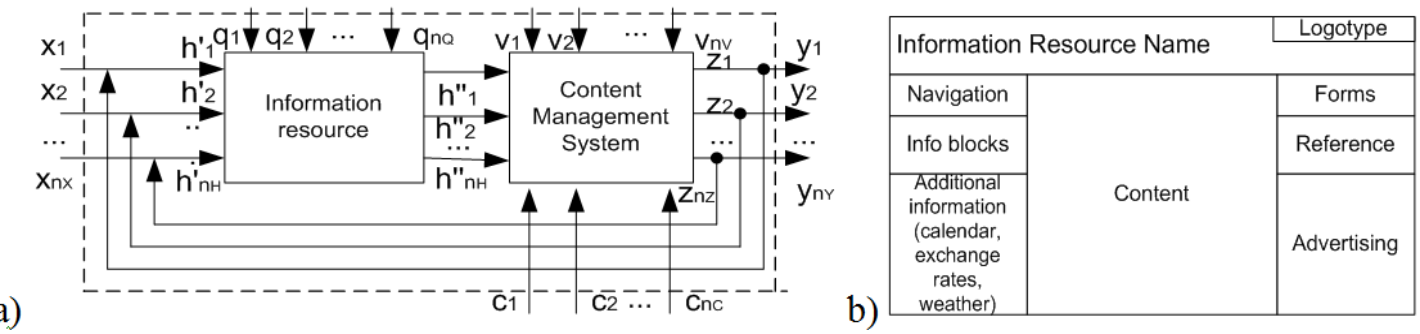

Fig. 10. Structure of a) content management system and b) information resource layout, developed by [10]

Table 4. Electronic content commerce tools classification

\begin{tabular}{|c|c|}
\hline Name & Definition \\
\hline $\begin{array}{l}\text { Corporative } \\
\text { Web-site }\end{array}$ & $\begin{array}{l}\text { Information page/resource with information about company, } \\
\text { project, content, activity type, proposals for cooperation. } \\
\text { Information resource with content about company, project, } \\
\text { commercial content, activity type, proposals for cooperation } \\
\text { etc., which has hierarchical structure and optimal scheme } \\
\text { of functioning. }\end{array}$ \\
\hline $\begin{array}{l}\text { Internet - } \\
\text { publishing } \\
\text { house }\end{array}$ & $\begin{array}{l}\text { Variety of Internet store, where product is thematic content } \\
\text { topical during certain time classified and submitted to infor- } \\
\text { mation resources. }\end{array}$ \\
\hline Provider & Access to the Internet and information services. \\
\hline $\begin{array}{l}\text { Internet } \\
\text { advertisement }\end{array}$ & $\begin{array}{l}\text { Commercial promotion of consumer product qualities in order } \\
\text { to increase demand. }\end{array}$ \\
\hline $\begin{array}{l}\text { Distance } \\
\text { education }\end{array}$ & $\begin{array}{l}\text { Profile courses or distance education (where content } \\
- \text { knowledge variety) with further specialty or document } \\
\text { about learning specialty receiving. }\end{array}$ \\
\hline Content portal & $\begin{array}{l}\text { Complicated system of company business processes and } \\
\text { content flows management is established on the basis } \\
\text { of corporative information resource and integrated with } \\
\text { ECCS. }\end{array}$ \\
\hline $\begin{array}{l}\text { Internet } \\
\text { marketing }\end{array}$ & $\begin{array}{l}\text { Production/sales activities management system of compa- } \\
\text { nies/firms, based on complex market analysis, demand, } \\
\text { prices, advertisement studying/forecasting, funding and } \\
\text { planning coordination, new content sorts creating etc. }\end{array}$ \\
\hline $\begin{array}{l}\text { Software } \\
\text { development }\end{array}$ & $\begin{array}{l}\text { Software designing, development and support on-line via } \\
\text { Internet. }\end{array}$ \\
\hline
\end{tabular}

Content management system, CMS is information system for information resources organization on the Internet, Intranet or Extranet [1, 2]. CMS process functioning output information is data about purpose and conditions of the system that determines main goal of modeling and allows formulating requirements to formal model of $S$ system and content management models. Content management system formal model is set of values $S=\langle X, Q, C, V, H$, Function, $T, Z, Y\rangle$, which describe system functioning process and create subsets, (Table 5 and Fig. 10) $[2,9,10]$.

Values $x_{i}, c_{r}, v_{l}, h_{k}, y_{j}$ are disjoint subsets elements and contain deterministic and stochastic components $[2,10]$. Incoming effects $x_{i}$, effects of the commercial content flow $c_{r}$, the external environment effects $E$ and internal system parameters are
Table 5. Content management system components

\begin{tabular}{|c|c|c|c|}
\hline Name & Marking & Range & Plural \\
\hline Input system effects & $x_{i} \in X$ & $i=\overline{1, n_{X}}$ & $X=\left\{x_{1}, x_{2} \ldots, x_{n_{X}}\right\}$ \\
\hline Users effects on system & $q_{d} \in Q$ & $d=\overline{1, n_{Q}}$ & $Q=\left\{q_{1}, q_{2} \ldots, q_{n_{Q}}\right\}$ \\
\hline $\begin{array}{c}\text { Content flow effects } \\
\text { on system }\end{array}$ & $c_{r} \in C$ & $r=\overline{1, n_{C}}$ & $C=\left\{c_{1}, c_{2} \ldots, c_{n_{C}}\right\}$ \\
\hline $\begin{array}{c}\text { External envirornment } \\
\text { effects on system }\end{array}$ & $v_{l} \in V$ & $l=\overline{1, n_{V}}$ & $V=\left\{v_{1}, v_{2}, \ldots, v_{n_{V}}\right\}$ \\
\hline $\begin{array}{c}\text { Internal system } \\
\text { parameters }\end{array}$ & $h_{k} \in H$ & $k=\overline{1, n_{H}}$ & $H=\left\{h_{1}, h_{2}, \ldots, h_{n_{H}}\right\}$ \\
\hline $\begin{array}{c}\text { System information } \\
\text { resource components }\end{array}$ & $z_{w} \in Z$ & $z=\overline{1, n_{Z}}$ & $Z=\left\{z_{1}, z_{2} \ldots, z_{n_{Z}}\right\}$ \\
\hline $\begin{array}{c}\text { Content management } \\
\text { transaction time }\end{array}$ & $t_{p} \in T$ & $p=\overline{1, n_{T}}$ & $T=\left\{t_{1}, t_{2} \ldots, t_{n_{T}}\right\}$ \\
\hline $\begin{array}{c}\text { Output system } \\
\text { characteristics }\end{array}$ & $y_{j} \in Y$ & $j=\overline{1, n_{Y}}$ & $Y=\left\{y_{1}, y_{2} \ldots y_{n_{Y}}\right\}$ \\
\hline
\end{tabular}

Table 6. Commercial content plural amount

\begin{tabular}{|l|c|c|}
\hline Content subset & Published & Not published \\
\hline Relevant & $a$ & $g$ \\
\hline Irrelevant & $b$ & $d$ \\
\hline
\end{tabular}

independent variables and output characteristics of the system are dependant. CMS $S$ work process described $y_{j}\left(t_{p}+\Delta t\right)=$ Function $\left(x_{i}, q_{d}, c_{r}, v_{l}, h_{k}, t_{p}, z_{w}\right)$, where $x_{i}$ is visitors/users requests to the content management system. According to Google Analytics [5] $y_{j}=\left\{a_{1}, a_{2}, \ldots, a_{m}\right\}$, where $a_{1}$ is number of visits over time $\Delta t ; a_{2}$ is average time on information resource (min, s); $a_{3}$ is fault indicator (\%); $a_{4}$ is reached aim; dynamics $(\%) ; a_{5}$ is total number of page views; $a_{6}$ is page views per visit; $a_{7}$ is new visitors $(\%) ; a_{8}$ is absolute unique visitors; $a_{9}$ is traffic sources $\%$ (search engines, direct traffic 
or other information resources) etc. [2]. Values effects $c_{r}, v_{l}, h_{k}$, on $z_{w}$ and $y_{j}$ as a CMS work result are unknown and unexplored $[1,2,10]$.

Formal CMS model does not reveal relations between input information, content, output information and content processing processes in system. Content commerce dynamics flow studying and information resources processing model building in CMS are important and actual [2]. For effective commerce content management process realization divide content plurality $c_{r}$ to relevant/irrelevant and published/unpublished subsets (Table 6), where content plurals quantity is equal to $a+b+d+g[1,2,6,9]$.

In Table 7 are formulas which calculate effectiveness indicators of commercial content search [1, 2, 6, 9]. One hundred percent quality search is impossible because of software tool power limit. Attempts are improved one of the parameters (accuracy/completeness) causes deterioration of another [6].

Dynamic flows of commercial thematic content are leads to limited models, opening way to further researches [1-11]. Content management models are assigned for content flow aging/topicality processes determination. They do not solve formation, content support problems. Commercial content lifecycle models authors suggest and describe several stages with set of properties that are supported by various technologies and processes (Table 8). In certain content lifecycle models project/content/ resource management concepts, information architecture, content strategies, semantic printing is foreseen. Different authors suggest various content lifecycle phases [1-9]. Main phases (content creation, development, view, spreading and activation) are present almost in all offered models [2]. Content management processes, actions, status and role lifecycles vary in models depending on organizational strategies, needs, requirements and possibilities of models $[2,9,16-32]$.

Considered content lifecycle models do not solve its formation and support problems and solve not all management problem: presentation set content to user according to his request, stories and information portfolio; automatic digest and information profile formation; thematic story detection and content meaning duplication; building relationship tables and content rating calculation; gathering data from various sources and their formatting; keywords and content notions detections; rubricating and content selective spreading. Existing e-commerce systems don't support all commercial content lifecycle and don't solve main information resources processing problems - content formation and support (Table 9). Lack of general and detailed classification of e-commerce content systems is leaded to the problem of defining and shaping general methods of design/development functioning architecture/algorithms of these systems. This justifies the research purpose, relevance, appropriateness and directions. Known technology of content management is Internet marketing with Internet-integration, information management, public relation, service work with customers and sales in different areas [1,2].

Internet marketing uses all aspects and the basic elements of traditional marketing, combined with new research methods and data analysis using modern technology (Fig. 11) [2].

Staying in constant contact with users is effective because of automatically tracking statistics. For its analysis return on investment, rate of return and conversion rate coefficients are used. Conversion or information resource visiting efficiency is relation of information resource visitors quantity, that complete targeted actions on it (hidden/direct advertisers instructions, sellers, commercial content authors, i.e. purchase, registration, subscription, information resource certain page visiting, ad-link transition), to total information resource visitors amount [2]. Successful conversion is differently interpretation by authors (customer buy operation, who got interested in product by clicking on the ad), advertisers or content providers (actions that are expected from visitors, for example: information resource visitors registration, mail subscription, software downloading). Internet marketing involves the use of strategies and trends of traditional direct response marketing and specialized areas of research that are applied to e-business Internet space. Internet marketing is not only content trading, but information space, software, business models etc. [1,2].

Table 7. Content search effectiveness indicators

\begin{tabular}{|c|c|c|c|}
\hline Coefficient & $\begin{array}{l}\text { Characterizes } \\
\text { a content part }\end{array}$ & $\begin{array}{c}\text { Around } \\
\text { content array }\end{array}$ & Formula \\
\hline Completeness & $\begin{array}{c}\text { Published } \\
\text { relevant }\end{array}$ & Relevant & $p=a /(a+g)$. \\
\hline Accuracy & $\begin{array}{c}\text { Published } \\
\text { relevant }\end{array}$ & published & $n=a /(a+b)$ \\
\hline Noise & $\begin{array}{l}\text { Published } \\
\text { irrelevant }\end{array}$ & Published & $e=b /(a+b)=1-n$ \\
\hline Sediment & $\begin{array}{l}\text { Published } \\
\text { irrelevant }\end{array}$ & Irrelevant & $q=b /(d+b)$. \\
\hline specificity & $\begin{array}{c}\text { Unseen } \\
\text { irrelevant }\end{array}$ & Irrelevant & $k=d /(d+b)$. \\
\hline
\end{tabular}

Table 8. Content lifecycle models classification, developed by [1, 2, 16-32]

\begin{tabular}{|l|l|c|c|c|}
\hline \multirow{2}{*}{ No } & \multirow{2}{*}{ Author } & \multicolumn{3}{|c|}{ Information resources processing } \\
\cline { 3 - 5 } & & Formation & Management & Support \\
\hline 1 & McKeever S. & $+/-$ & - & $+/-$ \\
\hline 2 & Bob Boiko & $+/-$ & $+/-$ & $+/-$ \\
\hline 3 & McGovern G. & $+/-$ & - & $+/-$ \\
\hline 4 & JoAnn Hackos & $+/-$ & - & $+/-$ \\
\hline 5 & Ann Rockley & $+/-$ & $+/-$ & $+/-$ \\
\hline 6 & Russell Nakano & $+/-$ & - & $+/-$ \\
\hline 7 & The State Victoria & $+/-$ & - & $+/-$ \\
\hline 8 & AIIM & $+/-$ & $+/-$ & $+/-$ \\
\hline 9 & CMP organization & $+/-$ & $+/-$ & - \\
\hline 10 & Bob Doyle & $+/-$ & $+/-$ & $+/-$ \\
\hline 11 & Woods Randy & $+/-$ & + & + \\
\hline 12 & Halverson & + & $+/-$ & $+/-$ \\
\hline
\end{tabular}

Table 9. Features comparison of electronic commerce systems and electronic content commerce systems

\begin{tabular}{|l|c|c|}
\hline \multicolumn{1}{|c|}{ System characteristic name } & E-commerce & $\begin{array}{c}\text { Electronic } \\
\text { content commerce }\end{array}$ \\
\hline Product immateriality & - & + \\
\hline Stable product quantity & - & + \\
\hline Product variety growth & $+/-$ & + \\
\hline Storehouse absences & - & + \\
\hline Keeping product in databases & - & + \\
\hline $\begin{array}{l}\text { Efficiency of product promotion } \\
\text { by keywords }\end{array}$ & $+/-$ & + \\
\hline $\begin{array}{l}\text { Efficiency of product search } \\
\text { by keywords }\end{array}$ & $+/-$ & + \\
\hline $\begin{array}{l}\text { Automatic detection and liquidation } \\
\text { of product duplication }\end{array}$ & - & + \\
\hline $\begin{array}{l}\text { Automatic product aging } \\
\text { determination by content }\end{array}$ & - & + \\
\hline $\begin{array}{l}\text { Automatic product topicality } \\
\text { determination }\end{array}$ & $+/-$ & + \\
\hline Automatic audience analysis & $+/-$ & + \\
\hline Automatic digest formation & - & + \\
\hline $\begin{array}{l}\text { Automatic distribution of products } \\
\text { between members }\end{array}$ & +- & + \\
\hline $\begin{array}{l}\text { Automatic distribution of digests } \\
\text { between workers }\end{array}$ & + & + \\
\hline Automatic product formation & + & + \\
\hline Automatic product formatting & + & + \\
\hline $\begin{array}{l}\text { User's experience effect on sales } \\
\text { amount increase }\end{array}$ & + & + \\
\hline
\end{tabular}


Google, Yahoo and MSN raised Internet-advertisement market on new level and segmented Internet-advertisement market, suggesting local advertising services to e-business. Through automation of audience research ROI increases and costs are reduced. The main advantages of online marketing: interactivity, the ability to make the most accurate targeting, the ability post click analysis to maximize performance information resource conversion and ROI / ROR online advertising $[1,2]$. The purpose of the online marketing technology using is the maximum effect getting of the potential audience of information resource with the possibility of instant obtaining of statistics about sales, visits, demand, etc. (Table 10) [1, 2].

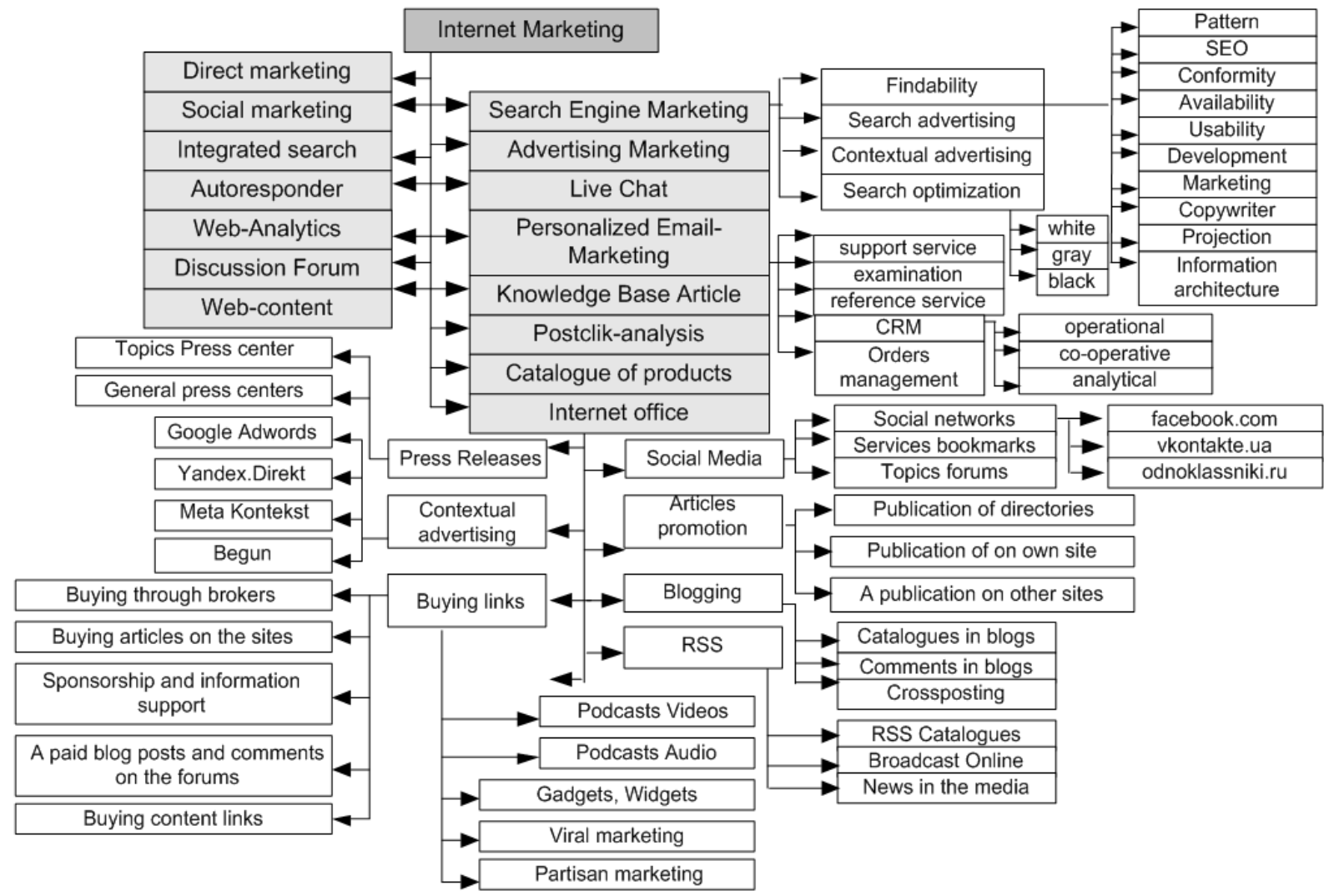

Fig. 11. Internet marketing directions

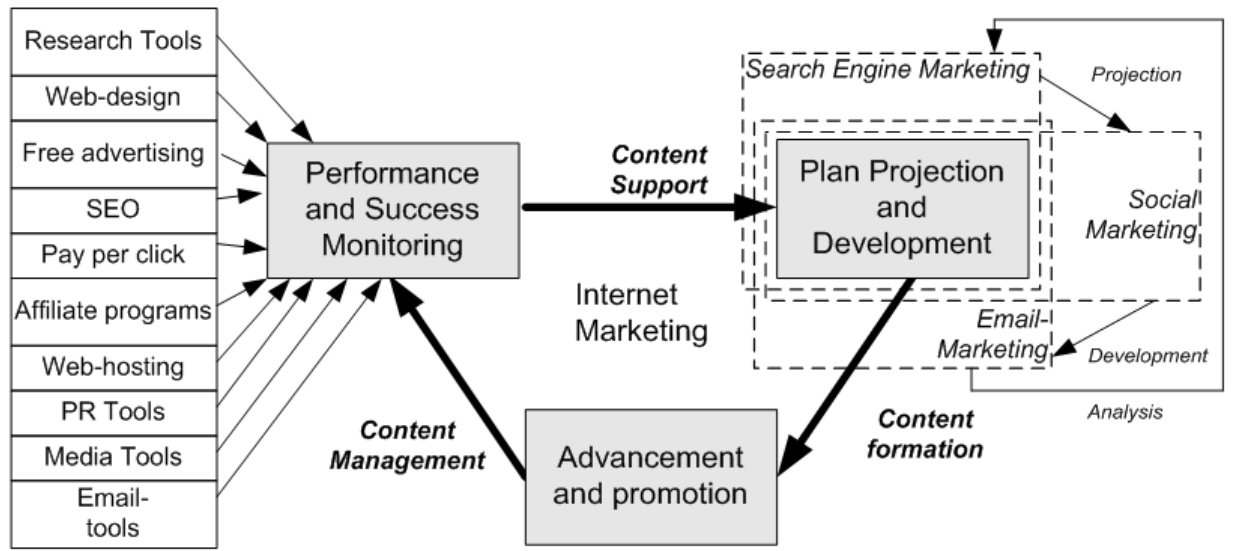

Fig. 12. Internet marketing for electronic content commerce systems

Table 10. Main Internet marketing benefits

\begin{tabular}{|l|l|}
\hline \multicolumn{1}{|c|}{ Name } & \multicolumn{1}{|c|}{ Definition } \\
\hline Interaction & $\begin{array}{l}\text { System organization principle, when aim is reached } \\
\text { by content exchange between system elements and } \\
\text { environment. }\end{array}$ \\
\hline $\begin{array}{l}\text { Search engine } \\
\text { marketing, SEM }\end{array}$ & $\begin{array}{l}\text { The process of increasing traffic from search engines, } \\
\text { the lists of search results and advertisements. }\end{array}$ \\
\hline $\begin{array}{l}\text { Targeted } \\
\text { advertising }\end{array}$ & $\begin{array}{l}\text { Advertising mechanism that allows to select target audience } \\
\text { that meets criteria to show it advertisement. }\end{array}$ \\
\hline $\begin{array}{l}\text { Post-click } \\
\text { analysis }\end{array}$ & $\begin{array}{l}\text { Method of Post-click marketing that maximizes efficiency } \\
\text { and information resource conversion and ROI of online } \\
\text { advertising. }\end{array}$ \\
\hline
\end{tabular}

Table 11. Main search marketing technologies

\begin{tabular}{|l|l|}
\hline Technology & \multicolumn{1}{|c|}{ Search marketing technology appointment } \\
\hline $\begin{array}{l}\text { Search } \\
\text { advertising }\end{array}$ & $\begin{array}{l}\text { Dissemination of information in search engines by placing ads } \\
\text { with keywords }[1,2] .\end{array}$ \\
\hline $\begin{array}{l}\text { Search } \\
\text { engine } \\
\text { optimization, } \\
\text { SEO }\end{array}$ & $\begin{array}{l}\text { The set of actions to change the state of information resource } \\
\text { promotion) and elements of external environment in order } \\
\text { to obtain high positions in search results for queries [1,2]. }\end{array}$ \\
\hline $\begin{array}{l}\text { Context } \\
\text { advertising }\end{array}$ & Placing advertisement on thematic information resources [1,2]. \\
\hline
\end{tabular}


Search Engine Marketing (Table 11) has the following features [1, 2]: work on the specific requests (keywords); relation with search (search engines, information resource search); increasing content findability on information resource; context analysis (content subject, information resource subject, etc.). Usability is overall comfort rate of object using; software user interfaces development concept, oriented for maximum psychological/visual user friendliness; efficiency coefficient of menu design and information resource navigation system performance; ease of use, friendly interface and usability of the software.

Search engine marketing is not reaching advertising purposes due to factors such as [2]: advertised product is not always directly reported; selling service/product is not always a purpose; difficult to increase brand awareness; impossible to bring a new product/service to market. Result of the search engine marketing use is $[1,2]$ : users attraction to the information resource, where for each individual case is different audience, therefore attracting wide (increasing the overall rate of information resource attendance) or interested audience; spread the content about the information resource in search engines.

The criterion for successful chosen search engine marketing strategy is the information resource visitors amount and the obtained by estimated audience quality accordance. A simple criterion of information resource popularity checking is the dynamics of the external links number on information resources and name mentions increasing of the product/service or trade mark in the Internet. The limiting case of search and contextual advertising is advertisements placing in thematic search results on information resource. The Internet development is contributed to the emergence of new technologies for social marketing optimization and video search marketing. Search engine marketing separation as a separate independent strategy is associated with continued growth of $[1,2]$ :

- the Internet market volume;

- the market for contextual and search advertising;

- the search engine optimization using [1,2];
- the need of optimal navigation and browsing in content area that contains textual, visual, animated and/or audio content and/or users experience of the system;

- complex process support of content lifecycle that it is passing during management through various stages of publication.

The ECCS designing and creation process by Internet marketing is an iterative. It proceeds from plan analysis, design and development to prototype creation and experimental tests. That is starting with the specifications and layout formation, template creation, content formation and its position according to the information resource structure (Fig. 12). Developers are focused solutions to business goals and end users needs.

At the initial stages before functional requirements determining and the process development beginning they are connected users by questionnaires, design alternatives and prototypes of varying degrees of readiness. That is collecting valuable information that is causing a direct involvement feeling in the user at the design process and is gaining their trust.

A well-known analysis method of textual information is content analysis. It is standard research method in the social sciences (Fig. 13), the object of which is to analyze the content of text arrays and communication correspondence (comments, forums, emails, articles, etc.). The concept of content analysis has no unambiguous definition $[2,9,11]$, so systems that are based on different approaches are incompatible. The use of content analysis of the text in the electronic commerce content systems has several advantages for simplifying business and solving a number of problems faced by participants in business processes, namely: user content filtering on information resource; the ability to automatically create a "portrait" of permanent user by analyzing his comments; the ability to automatically create a "portrait" of the target audience by analyzing the "portraits" of regular users; reduce the number of information resource moderators in ECCS; reducing the time for posting content to information resources through its automatic processing, not moderators; elimination of the language barrier through automatic creation of dictionaries and regular user automatic translation.

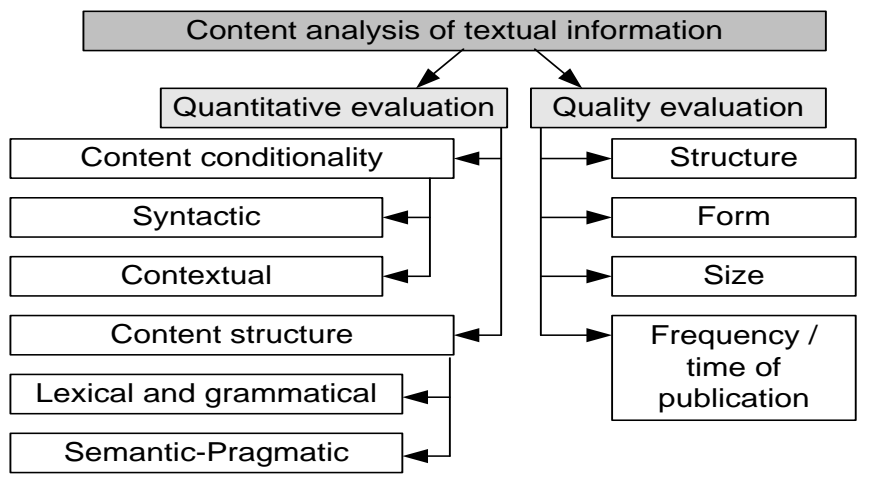

Fig. 13. Textual content analysis mechanism

Most definitions of content analysis are constructive, i.e. procedural. Due to different initial approaches they generate different algorithms, which sometimes contradict each other. Existing various approaches to content analysis understanding are criticized [11]. The biggest doubt is ignoring the role of context, but the practical value of the method avoids many contradictions.

Combining tools and methods and natural selection by repeated evaluation of the results make it possible to select or confirm knowledge and actual power/usefulness of the tools. Thus, content analysis - a quantitative and qualitative analysis of numerous texts for further meaningful interpretation of the quantitative and qualitative patterns. Content analysis used in the study of sources invariant in structure/content and existing as no systematic randomly organized text $[2,9,11]$. The content analysis method is the abstract model formation for content template with different textual set.
There are two methods of content analysis: quantitative and qualitative. In the study of the mechanisms of generating text in [9] found that the choice of models describing the content depends on the construction of probabilistic-linguistic testing and selection of some of its units. Simulation of the text and its components is the first step to describe the features of its linguistic units. Analysis of the language via probabilistic text modeling based on methods of quantitative linguistics, probability theory, mathematical statistics, information theory and combinatory. In linguistic studies, such as content search [9], there are tasks, associated with the a relevant number emergence prediction of classes' word forms/phrases in a given length segment. Modeling text, compositions, phrases, and grammar classes determines sample size that is required to provide with a certain probability of appearance at least once relevant linguistic unit [9]. Quantitative assessment of meaningful information in the text, words and phrases are based on the value of syntactic information 
and contextual conditioning [9]. Hypotheses about the most probabilistic extension text built on the basis of two types of combinatorial restrictions: combinatory figures (letters and syllables) and combinatory signs (morphemes, words, phrases) [9]. At the fifth text symbol step combinatory of letters and syllables are suppressed by restrictions that related to the compatibility of morphemes and words. When deploying text on word combinatorics restrictions are pilling with combination of phrases and sentences, limitations associated with combinatorics paragraphs, sections of the content. When guessing letters far enough from the beginning of the content is located, basing not on static letters and syllables combinatorics, but on meaningful (lexical and grammatical) text building. If the text removed from the initial portion of content serves as a quantitative assessment of the distribution and statistics of letters, the syntactic information from remote sites from the beginning of content serves as a reflection of the content (semantic-pragmatic) information. These considerations make it possible to offer content analysis method for quantitative evaluation of the content and information content segments.

Content tone determination based on text analysis is harder then spam detection. Finding spam considers two hypotheses (spam, not spam), determining tone requires emotional tone check (positive, negative, neutral) and their combinations. In Bayesian method for spam detection base assessments are used as two buildings content, one of which is made up of spam, and the other - no [7, 8]. For each content count frequency of each word and weighted score is from 0 to 1 , i.e. the conditional probability that the content of this word is spam $[7,8]$. Weights value close to $1 / 2$, not taken into account while integrated calculating, so words with such weights are ignored and deleted. On detecting new events from the stream of content, which series to the input ECCS from scanning tools or content router and caused by thematic query, new events are revealed, described in content $[7,8]$. Plot strings of similar content are formed for them. Content, which represents new event, is interdependent content cluster base (Table 12) $[7,8]$.
Main ECCS management tools is content management system $[1,2]$. CMS has to match certain set of requirements (Fig. 14). Usually such systems are used for saving and publishing huge content amount (documents, pictures, music, video etc.). Similar CMS allow managing textual and graphic filling, giving to user convenient information saving and publishing tools. CMS do not support all content flow lifecycle and do not solve main information resource processing problem - content support and formation [1,2]. Main CMS disadvantage is connection absence between incoming information, content and output information. CMS are often used to builds ECS and ECCS (Fig. 15) [1, 2].

Table 12. The process of new developments identifying

\begin{tabular}{|c|c|}
\hline Author & Stages of new process detection \\
\hline 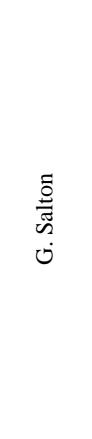 & $\begin{array}{l}\text { 1. First reviewed content is associated with first cluster. Each class } \\
\text { shown as terms vector (keywords), which are included in clusters } \\
\text { content. Normalized or approximated by certain criterion terms } \\
\text { vector is centroid. } \\
\text { 2. Each next content is compared with available clusters centroids } \\
\text { via measure of proximity. } \\
\text { 3. If content is close enough to certain cluster, than it is credited } \\
\text { to this cluster, where after appropriate centroid is recalculated. } \\
\text { 4. If content is not close to available clusters, then new cluster } \\
\text { is formed, and new content is credited to it. } \\
\text { 5. Content time range is an observation window. Cluster, all content } \\
\text { of which goes outside observation window, is not considered. } \\
\text { New event corresponds to each new cluster, shown is this cluster } \\
\text { content. }\end{array}$ \\
\hline 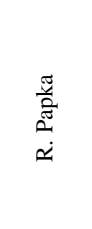 & $\begin{array}{l}\text { 1. Requests by themes formation (Text Mining is used to detect and } \\
\text { choose notions from content). } \\
\text { 2. New incoming content is compared with available requests. } \\
\text { 3. If content doesn't match requests, he is associated with new } \\
\text { event. } \\
\text { 4. New request is added into system, which matches such content } \\
\text { (optional). }\end{array}$ \\
\hline
\end{tabular}

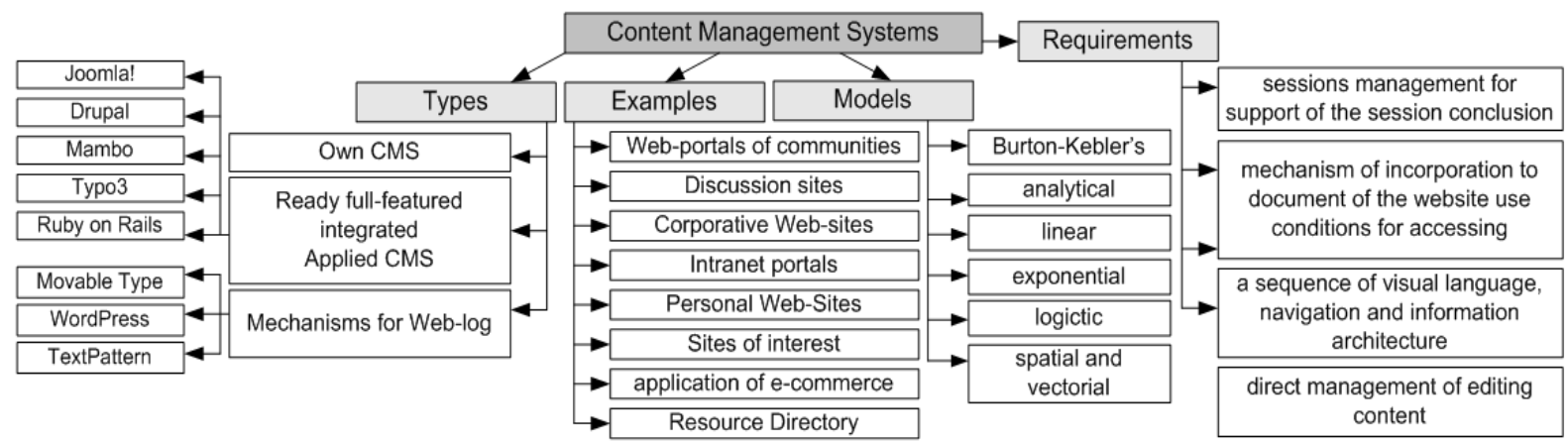

Fig. 14. Content management systems features

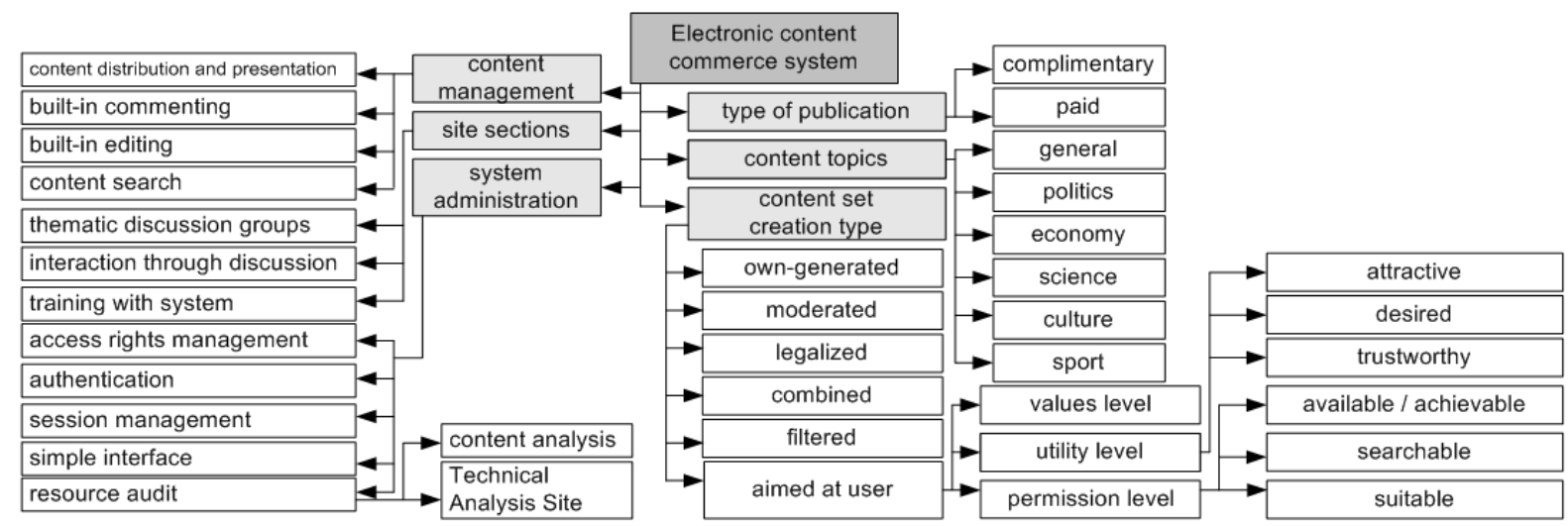

Fig. 15. Main components of ECCS 
Web Content management system, WCMS is a tool (Table 13) for modeling information resource branched structures in ECCS and managing their content $[1,2]$ without having special technical programming skills or html-layout. WCMS is developed for content generation in applications with such problems as dynamic gathering, content caching, safety etc. [1, 2]. CMS provides control on access information resource and alteration and designed to simplify as much as possible information resource management process while keeping setting and control flexibility. Main information resource components in CMS showed in Table 14. Content value determines his appeal for user. Content integration makes information resource attractive and application integration - useful. CMS using do not require software installation. Browser is used for editing and administrating. Intuitive system interface and work simplicity facilitates information resource management and lowers further spending on his support. CMS includes such possibilities: fast update and content search in information resource; data collection about clients and potential clients; surveys formation and editing; information resource visiting analysis.

Table 13. Main content management systems characteristic for ECCS, developed by [1, 2]

\begin{tabular}{|c|c|c|c|c|c|c|c|c|c|c|c|}
\hline \multirow{2}{*}{ CMS name } & \multicolumn{3}{|c|}{ Software requirements } & \multirow{2}{*}{ 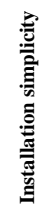 } & \multirow{2}{*}{ 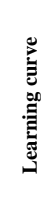 } & \multirow{2}{*}{ 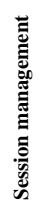 } & \multirow{2}{*}{ 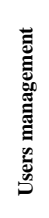 } & \multirow{2}{*}{ 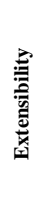 } & \multirow{2}{*}{ 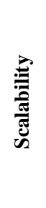 } & \multirow{2}{*}{ 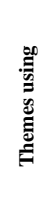 } & \multirow{2}{*}{ 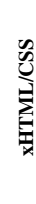 } \\
\hline & Web-server & Database & Language & & & & & & & & \\
\hline Ruby on Rails & $\begin{array}{l}\text { Apache, } \\
\text { FastCGI }\end{array}$ & $\begin{array}{l}\text { MySQL, PostgreSQL, } \\
\text { SQLite,Oracle, SQL } \\
\text { Serer, DB2, Firebird }\end{array}$ & Ruby & $+/-$ & $+1-$ & $+1-$ & $+1-$ & + & + & $+/-$ & + \\
\hline Drupal & Apache IIS & MySQL, PostgreSQL & PHP & $+/-$ & $+1-$ & + & + & + & + & + & + \\
\hline Mambo & Apache IIS & Apache IIS & PHP & + & $+1-$ & $+1-$ & + & $+1-$ & + & $+1-$ & + \\
\hline Typo3 & Apache IIS & Apache IIS & PHP & - & - & + & + & + & + & $+1-$ & \\
\hline Movable Type & Apache IIS, Jetty, Tomcat & Apache IIS, Jetty, Tomcat & Perl & + & $+1-$ & - & $+1-$ & $+1-$ & + & $+1-$ & - \\
\hline Word Press & Apache, mod_rewrite & Apache & PHP & + & - & - & $+1-$ & $+1-$ & - & $+/-$ & + \\
\hline Text Pattern & Apache & Apache & PHP & + & - & - & $+1-$ & - & - & $+/-$ & + \\
\hline Joomla! & Apache & MySQL & PHP & + & + & + & + & + & + & + & + \\
\hline
\end{tabular}

Table 14. Main content management components, developed by [1, 2]

\begin{tabular}{|l|l|}
\hline \multicolumn{1}{|c|}{ Name } & \multicolumn{1}{c|}{ Content management system characteristics } \\
\hline Menu items & Addition, editing, information resource of any level menu items management. \\
\hline Articles & Addition, editing, planning and articles publication (information resource pages). \\
\hline News & Addition, editing and news publication. \\
\hline Photo gallery & Possibility of galleries with under galleries work, automatic photo zooms. \\
\hline Notice board & Adverts with photo, description and contact details addition. \\
\hline Settings & All settings of information resource and his management system storage. \\
\hline Users & Rights management of registered users. \\
\hline Catalogue of companies & Addition, editing, publishing in under groups of any inset. \\
\hline Survey & Addition/editing of surveys, results as graphs. \\
\hline
\end{tabular}

\section{Conclusions}

An analysis of commercial content formation methods is made. And popular content lifecycle models and standardized content management services are researched. This gives possibility to determine requirements for creating optimal commercial content lifecycle. Internet technologies for construction of service oriented electronic commerce system are researched, what gave possibility to classify electronic commerce systems and electronic content commerce systems. In detail information resources and production processes of electronic commerce systems are reviewed, what gives possibility to develop optimal content lifecycle and typical electronic content commerce system architecture. The content management technology in electronic commerce is analyzed, what gives possibility to develop formal models, unified methods and software information resources processing in electronic content commerce systems. The modern methods and tools of electronic content commerce systems designing, modeling and realization from system approach position are analyzed. Also the necessity and feasibility of unified methods and information resources processing software creation is justified.

\section{References}

[1] Bereza A., Kozak I., Levchenko F.: Elektronna komertsiya. KNEU, Kyiv 2002.

[2] Berko A., Vysotska V., Pasichnyk V.: Electronic content commerce systems. NULP, Lviv 2009

[3] Bolshakova E., Klyshynskyy E., Lande D., Noskov A., Peskova O., Yahunova E.: Automatic processing of texts and computer linguistics. MYEM, Moskva 2011.

[4] Braychevskyy S., Lande D.: Modern information streams. Journal of Scientific and Technology info 11/2005, 21-33.

[5] Clifton B.: Google Analytics: professional attendance analysis web sites Williams, Moskva 2009.

[6] CM Lifecycle Poster. Content Management Professionals, 2010, http://www.cmprosold.org/resources/poster/> [14.02.2015]

[7] EMC, IBM, Microsoft: Content Management Interoperability Services. Appendices, Version 0.5, Hopkinton 2008.

[8] EMC, IBM, Microsoft: Content Management Interoperability Services. Part I. Version 0.5, Hopkinton 2008.

[9] EMC, IBM, Microsoft: Content Management Interoperability Services. Part II REST. Version 0.5, Hopkinton 2008.

[10] EMC, IBM, Microsoft: Content Management Interoperability Services. Part II SOAP. Version 0.5, Hopkinton 2008

[11] Fedasyuk D., Yakovyna V., Serdyuk P., Nytrebych O.: Variables state-based software usage model. Econtechmod, Vol. III, No 2, 15-20. Lublin 2014. 
[12] Fedorchuk A.: Content Monitoring information flows. Nat. Acad. Science Problems. Functioning, Trends of development. Vol. 3 http://www.nbuv.gov.ua/articles/2005/05fagmip.html [10.02.2015].

[13] Golota Y.: Logika antonimov i nechetkaya logika: skhodstva i razlichiya. International Conference on Soft Computing and Measurement, 208-210, Saint Petersburg 1998.

[14] Grinyaev S.: Nechetkaya logika v sistemah upravleniya. Kompyuterra-Onlayn No 38 (415), 2001, http://www.computerra.ru/offline/2001/4 [14.02.2015].

[15] Hackos J.: Content Management for Dynamic Web Delivery. Wiley, Hoboken 2002.

[16] Halvorson K.: Content Strategy for the Web. New Riders Press, 2009.

[17] Korneev B., Gareev A., Vasjutin S., Reich W.: Databases. Intelligent processing of information. Nolidg, Moskva 2000.

[18] Lande D.: Fundamentals of information streams integration. Engineering, Kyiv 2006.

[19] Lande D., Furashev V., Braychevskyy S., Grigoriev A.: Modeling and evaluation electronic information streams fundamentals. Engineering, Kyiv 2006

[20] Lytvyn V.: Design of intelligent decision support systems using ontological approach. Econtechmod, Vol. II, No 1, 2013, 31-38.

[21] Lytvyn V., Semotuyk O., Moroz O.: Definition of the semantic metrics on the basis of thesaurus of subject area. Econtechmod, 4/2013, 47-51.

[22] McGovern G. and Norton R. 2001. Content Critical. Upper Saddle River: FT Press, 256.

[23] McKeever S.: Understanding Web content management systems: evolution, lifecycle and market. Industrial Management \& Data Systems, 103/ 2003, 686-692.

[24] Nakano R.: Web content management: a collaborative approach. Addison Wesley Professional, Boston 2002.

[25] Osgood C.: The nature and measurement of meaning. Psychological Bulletin, 49/1952, 197-237.

[26] Papka R.: On-line News Event Detection, Clustering, and Tracking : thesis for the degree doctor of philosophy. Massachusetts University, Amherst 1999.

[27] Pospelov D.: Situatsionnoe upravlenie: teoriya i praktika. Nauka, Moskva 1986.

[28] Rockley A.: Managing Enterprise Content: A Unified Content Strategy. New Riders Press, 2002.

[29] Rybytska O., Vovk M. An application of the fuzzy set theory and fuzzy logic to the problem of predicting the value of goods rests. Econtechmod, Vol. III, No 2, 2014, 65-69.

[30] Ryshkovets Yu., Zhezhnych P.: Information model of Web-gallery taking into account user's interests. Econtechmod, Vol. II, No 3, 2013, 59-63.

[31] Sovetov B., Yakovlev S.: Systems Modeling. VSH. Moskva 1998.

[32] Stone W.R.: Plagiarism, Duplicate Publication and Duplicate Submission: They Are All Wrong! IEEE Antennas and Propagation, Vol. 45, 4/2003, 47-49.

[33] Sullivan D.: Invisible Web Gets Deeper. Search Engine Report, 2002, http://searchenginewatch.com/sereport/article.php/2162871 [10.02.2015].

[34] The Content Management Possibilities Poster. Metatorial Services, Inc., 2010, http://metatorial.com/pagea.asp?id=poster [14.02.2015]

[35] Vysochina M.: The innovative approach to the study of decision-making in the context of the specific character of a product of managerial work. Econtechmod, Vol. III, No 2, 2014, 87-92.

[36] Vysotska V., Sherbyna Y., Pasichnyk B., Shestakevich T.: Mathematical linguistics. "Novy Svit - 2000", Lviv 2012.

[37] Woods R.: Defining a Model for Content, 2010, http://www.contentmanager.net/magazine/article_785_defining_a_model_for_c ontent_governance.html [14.02.2015].

[38] Zade L.: Ponyatie lingvisticheskoy peremennoy i ego primenenie k prinyatiyu resheny. Mir, Moskva 1976
Ph.D. Victoria Vysotska

e-mail: victana@bk.ru, victoria.a.vysotska@lpnu.ua

Associate Professor of Information Systems and Networks Department, Institute of Computer Science and Information Technology at Lviv Polytechnic National University, Lviv, Ukraine. Victoria has over 10 years of teaching, about 90 publications in various national and international journals and conferences.

Research interests: information systems and networks, ecommerce, information resources, commercial content, content analysis, content monitoring, content search, electronic content commerce systems, software systems, models, algorithms, analysis, methods and strategies of systems design.

\section{Ph.D. Lyubomyr Chyrun}

e-mail: chyrunlv@mail.ru

Associate Professor of Software Department, Institute of Computer Science and Information Technology at Lviv Polytechnic National University, Lviv, Ukraine. He has over 10 years of teaching, research and consultancy experience and has been key note speakers and about 60 publication in various national and international conferences in Ukraine and abroad. Research interests: software, information systems and networks, ecommerce, information resources, commercial content, content analysis, content monitoring, content search, electronic content commerce systems, software systems, models, algorithms, analysis, methods and strategies of systems design.

Pavlo Kozlov

e-mail:pblcbko@gmail.com

Born 28 April 1994 in Lviv, Ukraine. Finished Lviv Academic Gymnasium. Then entered Lviv Polytechnic National University where currently studying at the Information Systems and Networks Department as a student.
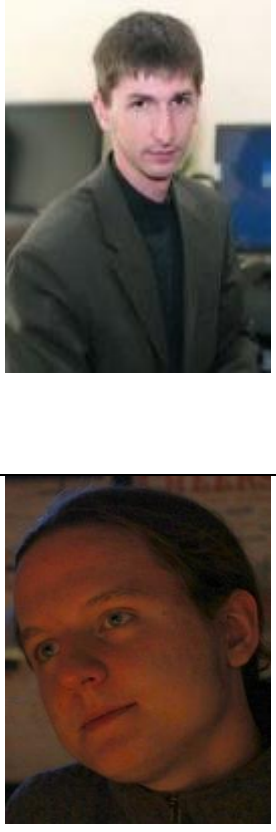

otrzymano/received: 01.05.2015 przyjęto do druku/accepted: 31.03 .2016 